\title{
ANALISIS PERBANDINGAN KINERJA KEUANGAN BANK KONVENSIONAL DAN BANK SYARIAH PERIODE 2013-2016
}

\author{
Yosi Stefhani \\ Program Studi Manajemen Universitas Satya Negara Indonesia \\ yosi.stefhani@yahoo.com
}

\begin{abstract}
The purpose of this study is to see whether there is a difference between the financial performance of conventional banks and sharia banks period 2013-2016. Financial performance indicators used in this study are financial ratios of CAR, LDR / FDR, NPL / NPF, BOPO and ROA. In this study the conventional bank samples used are Bank Mandiri, Bank BCA and Bank BNI. Meanwhile, the sharia bank sample in this research is Bank Mandiri Syariah, Bank BCA Syariah and Bank BNI Syariah. Data analysis method used in this research is descriptive analysis and Wilcoxon Signed Ranks test. Based on the results of data analysis and Wilcoxon Signed Ranks test, the result shows that there is no difference of financial performance between conventional bank and syariah bank by using CAR, LDR / FDR and NPL / NPF indicator, but if using BOPO and ROA indicator there is difference between conventional banks and sharia banks. The results also show BOPO and conventional bank ROA better than BOPO and ROA of sharia bank.
\end{abstract}

Keywords: Banking Performance, Conventional Bank, Sharia Bank, Financial Ratio

\section{PENDAHULUAN}

Peran perbankan dalam sistem perekonomian suatu negara sudah tidak diragukan lagi mempunyai peranan yang sangat penting. Fungsi bank sebagai financial intermediary yaitu sebagai lembaga yang dapat menghimpun dana dari masyarakat dan menyalurkannya kemballi kepada masyarakat. Dana yang disalurkan diharapkan digunakan untuk sesuatu yang produktif terutama di sektor riil sehingga mampu meningkatkan pendapatan masyarakat dan pada akhirnya mampu meningkatkan pertumbuhan ekonomi suatu negara. Dengan demikian secara tidak langsung bank mampu membantu dan mendukung pemerintah dalam rangka melakukan pembangunan nasional. Mengingat pentingnya peran perbankan tersebut maka kinerja perbankan menjadi hal yang patut diperhatikan. Dengan kinerja perbankan yang bagus menjadi salah satu indikator peran perbankan telah dilaksanakan secara maksimal. Kinerja perbankan salah saunya dilihat dari kinerja keuangannya. Melihat perkembangan industri perbankan yang ada di Indonesia sekarang ini maka tidak hanya bank konvensional yang ada tapi ada juga bank syariah. Perbedaan yang paling prinsip antara adalah sistem bagi hasil bank syariah dan sistem bunga bank konvensional dalam pengelolaan keuangan. Perbedaan ini juga kemudian membuat beberapa indikator kinerja bank syariah dan bank konvensional berbeda terutama kinerja keuangan. Sistem bagi hasil yang tidak memperbolehkan bunga (riba) membuat penyaluran dana dari bank syariah bukan merupakan pinjaman (kredit) tapi merupakan pembiayaan dengan konsep bagi hasil. Dengan sistem pengelolaan pendanaan yang berbeda berpotensi menyebabkan perbedaan kinerja bank konvensional dan bank syariah terutama terkait kinerja keuanganannya. Kinerja keuangan yang bisa diukur menggunakan rasio keuangan menunjukan perbedaan indikator kinerja keuangan antara bank konvensional dan bank syariah. 
Berbagai penelitian terkait perbandingan kinerja keuanganan antara bank konvensional dan bank syariah telah banyak dilakukan. Penelitian yang dilakukan Hanina dkk (2017) menunjukan hasil penelitian terkait kinerja bank konvensional dan bank syariah bahwa terdapat perbedaan kinerja keuangan dengan menggunakan indikator CAR, BOPO dan LDR/FDR antara bank konvensional dan bank syariah sementara itu tidak terdapat perbedaan kinerja keuangan dengan menggunakan indikator NPL/NPF dan ROA antara bank konvensional dan bank syariah. Penelitian yang dilakukan Gusti dkk (2016) hasil penelitiannya menunjukan terdapat perbedaan kinerja keuangan dengan menggunakan indikator ROA antara bank konvensional dan bank syariah. Hasil penelitian Gusti dkk juga menunjukan bahwa ROA bank konvensional lebih tinggi dibandingkan bank syariah. Penelitian lainnya yang dilakukan oleh Yudiana dkk (2015) hasil penelitian menunjukan terdapat perbedaan kinerja keuangan dengan indikator ROA, BOPO dan LDR/FDR antara bank konvensional dan bank syariah tapi tidak terdapat perbedaan kinerja keuangan dengan indikator CAR dan ROE.

Maka berdasarkan penjelasan diatas dan masih adanya perbedaan hasil penelitian sebelumnya maka penelitian selanjutnya masih layak untuk dilakukan. Untuk itu penulis tertarik untuk melakukan penelitian dengan judul Perbandingan Kinerja Perbankan Konvensional dan Perbankan Syariah Periode 2013-2016.

\section{KERANGKA PEMIKIRAN TEORITIS}

Bank menurut UU No.10 tahun 1998 memiliki definisi sebagai lembaga yang menghimpun dana dari masyarakat dan menyalurkannya kembali kepada masyarakat dalam bentuk kredit atau bentuk lainnya dengan tujuan untuk meningkatkan kesejahteraan masyarakat. Selain kegiatan menghimpun dan menyalurkan dana bank juga memberikan pelayanan bank lainnya dalam hal pembayaran dan peredaran uang. Maka secara singkat bank menjalankan fungsi (1) menghimpun dana dari masyarakat dan menyalurkan dana kepada masyarakat (2) menciptakan alat pembayaran yang efisien dalam aktivitas ekonomi (3) menyediakan pelayanan keuangan lainnya.

Bank syariah didefinisikan sebagai bank yang menjalankan kegiatannya berdasarkan pada prinsip syariah. Salah satu prinsip syariah yang diterapkan dalam kegiatan bank syariah adalah prinsip bagi hasil dalam hal pengelolaan dananya. Bank syariah tidak mengenal konsep bunga (riba) karena konsep ini tidak sesuai dengan prinsip syariah. Bank syariah memiliki prinsip dasar yang digunakannya dalam melakukan kegiatan usahanya diantaranya :

1. Tidak ada riba.

2. Mengedepankan kepentingan masyarakat dan berusaha mewujudkan tujuan ekonomi syariah.

3. Bank syariah secara operasional merupakan gabungan antara bank konvensional dan bank investasi.

4. Melakukan seleksi yang lebih ketat dan lebih hati-hati untuk setiap pengajuan pembiayaan yang berorientasi pada penyertaan modal.

5. Konsep bagi hasil yang diterapkan cenderung mempererat hubungan antara bank syariah dan penerima pembiayaan.

6. Bank syariah memanfaatkan instrument pasar uang antar bank syariah dan instrument bank sentral berbasis syariah untuk meningkatkan likuiditasnya.

Dengan demikian maka perbedaan antara bank konvensional dan bank syariah dapat dijabarkan dalam tabel berikut ini.

Tabel 1

Perbedaan Bank Konvensional dan Bank Syariah 


\begin{tabular}{|l|l|}
\hline \multicolumn{1}{|c|}{ Bank Konvensional } & \multicolumn{1}{|c|}{ Bank Syariah } \\
\hline $\begin{array}{l}\text { Melakukan investasi yang sesuai prinsip } \\
\text { syariah dan yang tidak sesuai prinsip syariah }\end{array}$ & $\begin{array}{l}\text { Melakukan investasi yang sesuai dengan prinsip } \\
\text { syariah }\end{array}$ \\
\hline Menerapkan konsep bunga (riba) & Menerapkan konsep bagi hasil \\
\hline Berorientasi pada keuntungan & $\begin{array}{l}\text { Tidak hanya berorientasi pada keuntungan tapi } \\
\text { juga kebahagiaan dunia akhirat }\end{array}$ \\
\hline $\begin{array}{l}\text { Tidak memiliki dewan pengawas seperti } \\
\text { dewan pengawas syariah di bank syariah }\end{array}$ & $\begin{array}{l}\text { Kegiatan utamanya dilakukan berdasarkan } \\
\text { fatwa Dewan Pengawas Syariah }\end{array}$ \\
\hline
\end{tabular}

Sumber : Buku Bank Syariah:Teori dan Praktik, M. Syafii Antonio

Kinerja keuangan menggambarkan kemampuan perusahaan dalam memilih dan mengelola sumber daya yang dimiliki oleh satu perusahaan. Penilaian kinerja keuangan pada umumnya menggunakan berbagai pendekatan diantaranya menggunakan pendekatan analisa rasio. Pendekatan analisa rasio adalah analisis yang dilakukan dengan cara membandingkan akun-akun yang ada dalam laporan keuangan sehingga menghasilkan suatu rasio. Analisa rasio yang digunakan dalam rangka penilaian kinerja keuangan suatu perusahaan menjadi berbeda-beda tergantung dimana perusahaan tersebut bergerak di sektor bisnis mana. Contohnya saja analisa rasio keuangan pada perusahaan manufacture dengan perbankan mempunyai perbedaan.

Analisa rasio juga digunakan dalam melakukan penilaian kinerja keuangan perbankan. Analisa rasio yang diterapkan di penilaian kinerja keuangan perbankan juga bisa untuk menilai kesehatan bank tersebut. Sementara itu analisa rasio pada sektor perbankan memiliki prinsip yang sama pada dasarnya jika diterapkan pada bank konvensional maupun bank syariah.

Beberapa rasio yang digunakan dalam penilaian kinerja keuangan untuk sektor perbankan baik bank konvensional dan bank syariah diantaranya :

1. Capital Adequacy Ratio (CAR)

Capital Adequacy Ratio (CAR) adalah rasio kecukupan modal yang dimiliki oleh bank dalam membiaya aktivitas kegiatannya dalam hal ini yang menunjang aktiva yang menghasilkan resiko seperti kredit yang disalurkan. Rumus CAR adalah sebagai berikut :

$\mathrm{CAR}=\frac{\text { Modal Bank }}{\text { Aktiva Tertimbang Menurut Resiko }} \times 100 \%$

2. Financing Deposit Ratio (FDR)/Loan Deposit Ratio (LDR)

Rasio ini mengukur tingkat likuiditas bank dengan cara membanding antara pembiayaan/pinjaman yang disalurkan dengan deposit/simpananyang berasal dari dana pihak ketiga yang dimiliki bank. Rumus FDR/LDR adalah sebagai berikut :

$$
\begin{aligned}
& \mathrm{FDR}=\frac{\text { Pembiayaan }}{\text { Dana Pihak Ketiga }} \times 100 \% \\
& \mathrm{LDR}=\frac{\text { Pinjaman }}{\text { Dana Pihak Ketiga }} \times 100 \%
\end{aligned}
$$

3. Net Performing Financing (NFP)/Net Performing Loan (NPL)

Rasio ini mengukur risiko bank dalam pengelolaan pembiayaan/pinjaman yang disalurkan. Rumus NFP/LDR adalah sebagai berikut :

$$
\mathrm{NPF}=\frac{\text { Pembiayaan Bermasalah }}{\text { Total Pembiayaan Yang Disalurkan }} \times 100 \%
$$


$\mathrm{NPL}=\frac{\text { Kredit Bermasalah }}{\text { Total Kredit Yang Disalurkan }} \times 100 \%$

4. Biaya Operasional terhadap Pendapatan Operasional (BOPO)

Rasio BOPO merupakan rasio yang digunakan untuk menilai aspek efisiensi. Aspek ini mengukur bagaimana kemampuan bank dalam pengelolaan dana yang dimiliki dan biayayang harus dikeluarkannya. Rumus BOPO adalah sebagai berikut:

BOPO $=\frac{\text { Biaya Operasional }}{\text { Pendapatan Operasional }} \times 100 \%$

5. Return on Assets (ROA)

Rasio ini merupakan rasio yang mengukur kemampuan bank dalam menghasilkan laba dari pengelolaan asset yang dimiliki bank. Rumus ROA adalah sebagai berikut :

$$
\text { ROA }=\frac{\text { Laba Bersih }}{\text { Total Assets }} x 100 \%
$$

6. Return on Equity (ROE)

Rasio ini merupakan rasio yang mengukur kemampuan bank dalam menghasilkan laba dari modal sendiri yang dimiliki bank. Rumus ROE adalah sebagai berikut :

$$
\mathrm{ROE}=\frac{\text { Laba Bersih }}{\text { Total Modal Sendiri }} x \mathbf{1 0 0} \%
$$

7. Net Profit Margin (NPM)

Rasio ini merupakan rasio yang mengukur kemampuan perusahaan dalam menghasilkan laba dari pendapatan operasional yang diperoleh bank. Rumus NPM adalah sebagai berikut :

$$
\mathrm{NPM}=\quad \frac{\text { Laba Bersih }}{\text { Pendapatan Operasional }} x \mathbf{1 0 0} \%
$$

\section{Penelitian Sebelumnya Yang Relevan}

Penelitian-penelitian sebelumnya terkait perbandingan kinerja perbankan konvensional dan perbankan syariah telah banyak dilakukan. Berikut ini merupakan beberapa penelitianpenelitian sebelum yang relevan selama 5 tahun terakhir:

\begin{tabular}{|c|c|c|c|}
\hline Tahun & Peneliti & $\begin{array}{c}\text { Variabel Dan } \\
\text { Metode Analisis }\end{array}$ & Hasil Penelitian \\
\hline 2017 & $\begin{array}{l}\text { - Hanina Maya } \\
\text { Solikah } \\
\text { - Ronny } \\
\text { Malavia } \\
\text { Mardani } \\
\text { - Budi Wahono }\end{array}$ & $\begin{array}{l}\text { Variabel Yang } \\
\text { Diteliti : } \\
\text { - } \quad \text { CAR } \\
\text { - } \quad \text { NPL/NPF } \\
\text { - } \quad \text { ROA } \\
\text { - } \quad \text { BOPO } \\
\text { - } \quad \text { LDR/FDR } \\
\text { Metode Analisis: } \\
\text { Independent Sample } \\
\text { T Test }\end{array}$ & $\begin{array}{l}\text { - } \text { Terdapat Perbedaan rasio CAR Bank } \\
\text { Konvensional dan Bank Syariah } \\
\text { - Tidak Terdapat Perbedaan rasio NPL } \\
\text { Bank Konvensional dan NPF Bank } \\
\text { Syariah } \\
\text { - Tidak Terdapat Perbedaan rasio ROA } \\
\text { Bank Konvensional dan Bank Syariah } \\
\text { - Terdapat Perbedaan rasio BOPO Bank } \\
\text { Konvensional dan Bank Syariah } \\
\text { Terdapat Perbedaan rasio LDR Bank } \\
\text { Konvensional dan FDR Bank Syariah }\end{array}$ \\
\hline 2016 & $\begin{array}{l}\text { - Gusti Ayu } \\
\text { Yuliani } \\
\text { Purnamasari }\end{array}$ & $\begin{array}{l}\text { Variabel Yang } \\
\text { Diteliti : } \\
\text { - CAR }\end{array}$ & $\begin{array}{l}\text { - Kinerja keuangan dengan menggunakan } \\
\text { indikator ROA menunjukan perbedaan } \\
\text { antara ROA Bank Konvensional dan }\end{array}$ \\
\hline
\end{tabular}

Tabel 2.

Penelitian Terdahulu yang Relevan 


\begin{tabular}{|c|c|c|c|}
\hline & $\begin{array}{l}\text { - Dodik } \\
\text { Ariyanto }\end{array}$ & $\begin{array}{l}\text { - } \quad \text { NPL/NPF } \\
\text { - } \quad \text { ROA } \\
\text { - } \quad \text { BOPO } \\
\text { - } \quad \text { LDR/FDR } \\
\text { Metode Analisis: } \\
\text { Uji Beda dan } \\
\text { Deskriptif }\end{array}$ & $\begin{array}{l}\text { Bank Syariah. } \\
\text { Tingkat ROA Bank Konvensional lebih } \\
\text { tinggi dibandingkan dengan ROA Bank } \\
\text { Syariah. }\end{array}$ \\
\hline 2016 & $\begin{array}{l}\text { - Sasa Elida } \\
\text { Sovia } \\
\text { - Muhammad } \\
\text { Saifi } \\
\text { - Achmad } \\
\text { Husaini }\end{array}$ & $\begin{array}{l}\text { Variabel Yang } \\
\text { Diteliti : } \\
\text { - } \quad \text { CAR } \\
\text { - } \quad \text { NPL/NPF } \\
\text { - } \quad \text { ROA } \\
\text { - } \quad \text { BOPO } \\
\text { - } \quad \text { LDR/FDR } \\
\text { Metode Analisis: } \\
\text { Analisa Deskriptif } \\
\text { dan Analisis } \\
\text { Independent Sample } \\
\text { T Test } \\
\end{array}$ & $\begin{array}{l}\text { - } \text { Terdapat Perbedaan rasio ROA Bank } \\
\text { Konvensional dan Bank Syariah } \\
\text { - Terdapat Perbedaan rasio BOPO Bank } \\
\text { Konvensional dan Bank Syariah } \\
\text { - Terdapat Perbedaan rasio LDR Bank } \\
\text { Konvensional dan FDR Bank Syariah } \\
\text { - Terdapat Perbedaan rasio NPL Bank } \\
\text { Konvensional dan NPF Bank Syariah } \\
\text { - Tidak Terdapat Perbedaan rasio CAR } \\
\text { Bank Konvensional dan Bank Syariah } \\
\text { - Tidak Terdapat Perbedaan rasio NIM } \\
\text { Bank Konvensional dan Bank Syariah } \\
\end{array}$ \\
\hline 2015 & $\begin{array}{l}\text { - Yudiana } \\
\text { Febrita Putri } \\
\text { - Isti Fadah }\end{array}$ & $\begin{array}{l}\text { Variabel Yang } \\
\text { Diteliti : } \\
\text { - } \quad \text { CAR } \\
\text { - } \quad \text { NPL/NPF } \\
\text { - } \quad \text { ROA } \\
\text { - } \quad \text { BOPO } \\
\text { - } \quad \text { LDR/FDR } \\
\text { Metode Analisis: } \\
\text { Independent Sample } \\
\text { T Test }\end{array}$ & $\begin{array}{l}\text { - Terdapat Perbedaan rasio ROA Bank } \\
\text { Konvensional dan Bank Syariah } \\
\text { - Terdapat Perbedaan rasio BOPO Bank } \\
\text { Konvensional dan Bank Syariah } \\
\text { - Terdapat Perbedaan rasio LDR Bank } \\
\text { Konvensional dan FDR Bank Syariah } \\
\text { Tidak Terdapat Perbedaan rasio CAR } \\
\text { Bank Konvensional dan Bank Syariah } \\
\text { - Tidak Terdapat Perbedaan rasio ROE } \\
\text { Bank Konvensional dan Bank Syariah } \\
\text { - Tidak Terdapat Perbedaan rasio NPL } \\
\text { Bank Konvensional dan NPF Bank } \\
\text { Syariah }\end{array}$ \\
\hline 2013 & $\begin{array}{l}\text { - Ari } \\
\text { Setyaningsih } \\
\text { - Setyaningsih } \\
\text { Sri Utami }\end{array}$ & $\begin{array}{l}\text { Variabel Yang } \\
\text { Diteliti : } \\
\text { - } \quad \text { CAR } \\
\text { - } \quad \text { NPL/NPF } \\
\text { - } \quad \text { ROA } \\
\text { - } \quad \text { BOPO } \\
\text { - } \quad \text { LDR/FDR } \\
\text { Metode Analisis: } \\
\text { Analisa Deskriptif }\end{array}$ & $\begin{array}{l}\text { 1. CAR Bank Konvensional lebih baik } \\
\text { dibandingkan dengan Bank Syariah } \\
\text { 2. NPF Bank Syariah lebih baik } \\
\text { dibandingkan dengan NPL Bank } \\
\text { Konvensional } \\
\text { 3. ROA Bank Konvensional lebih baik } \\
\text { dibandingkan dengan Bank Syariah } \\
\text { 4. BOPO Bank Konvensional lebih baik } \\
\text { dibandingkan dengan Bank Syariah } \\
\text { 5. LDR Bank Konvensional lebih baik } \\
\text { dibandingkan dengan FDR Bank Syariah }\end{array}$ \\
\hline
\end{tabular}

Sumber : Dari Berbagai Jurnal Terpublikasi

Hipotesis yang diajukan dalam penelitian ini adalah :

Hipotesis 1:

Ho : Tidak terdapat perbedaan kinerja keuangan dengan indikator CAR antara bank konvensional dan bank syariah

Ha $\quad$ : Terdapat perbedaan kinerja keuangan dengan indikator CAR antara bank konvensional dan bank syariah

Hipotesis 2:

Ho $\quad$ : Tidak terdapat perbedaan kinerja keuangan dengan indikator FDR/LDR antara bank konvensional dan bank syariah 
Ha : Terdapat perbedaan kinerja keuangan dengan indikator FDR/LDR antara bank konvensional dan bank syariah

Hipotesis 3:

Ho $\quad$ : Tidak terdapat perbedaan kinerja keuangan dengan indikator NPF/NPL antara bank konvensional dan bank syariah

Ha $\quad$ : Terdapat perbedaan kinerja keuangan dengan indikator NPF/NPL antara bank konvensional dan bank syariah

Hipotesis 4:

Ho : Tidak terdapat perbedaan kinerja keuangan dengan indikator BOPO antara bank konvensional dan bank syariah

Ha $\quad$ : Terdapat perbedaan kinerja keuangan dengan indikator BOPO antara bank konvensional dan bank syariah

Hipotesis 5:

Ho

: Tidak terdapat perbedaan kinerja keuangan dengan indikator ROA antara bank konvensional dan bank syariah

Ha : Terdapat perbedaan kinerja keuangan dengan indikator ROA antara bank konvensional dan bank syariah

\section{METODE}

\section{Sampel Penelitian}

Penelitian ini merupakan studi kasus pada Bank Mandiri, Bank BCA, Bank BNI dan Bank Mandiri Syariah, Bank BCA Syariah dan Bank BNI Syariah periode 2013-2016.

\section{Jenis Penelitian}

Penelitian ini adalah penelitian deskriptif komparatif yaitu jenis penelitian yang menjelaskan semua variabel yang ditelitisecara detail kemudian membandingkan variabel yang sama antar sampel yang berbeda.

\section{Jenis dan Sumber Data}

Penelitian ini menggunakan data sekunder. Data sekunder merupakan data yang diperoleh tidak secara langsung dari sumbernya. Data sekunder yang digunakan dalam penelitian ini adalah data-data laporan keuangan bank yang dperoleh dari website setiap bank yang menjadi sampel penelitian ini. Laporan keuangan perbankan wajib dipublikasikan dan dilaporkan. Publikasi laporan keuangan perbankan salah satunya melalui website bank masing-masing.

\section{Definisi Operasional Variabel dan Skala Pengukuran}

Variabel penelitian dan definisi operasional berdasarkan pada masalah dan hipotesis yang akan di uji, yaitu sebagai berikut :

1. Capital Adequacy Ratio (CAR)

Capital Adequacy Ratio (CAR) adalah rasio kecukupan modal yang dimiliki oleh bank dalam membiaya aktivitas kegiatannya dalam hal ini yang menunjang aktiva yang menghasilkan resiko seperti kredit yang disalurkan. Rumus CAR adalah sebagai berikut :

$\mathrm{CAR}=\frac{\text { Modal Bank }}{\text { Aktiva Tertimbang Menurut Resiko }} \times 100 \%$

2. Financing Deposit Ratio (FDR)/Loan Deposit Ratio (LDR)

Rasio ini mengukur tingkat likuiditas bank dengan cara membanding antara pembiayaan/pinjaman yang disalurkan dengan deposit/simpananyang berasal dari dana pihak ketiga yang dimiliki bank. Rumus FDR/LDR adalah sebagai berikut : 


$$
\begin{aligned}
& \mathrm{FDR}=\frac{\text { Pembiayaan }}{\text { Dana Pihak Ketiga }} \times 100 \% \\
& \mathrm{LDR}=\frac{\text { Pinjaman }}{\text { Dana Pihak Ketiga }} \times 100 \%
\end{aligned}
$$

3. Net Performing Financing (NFP)/Net Performing Loan (NPL)

Rasio ini mengukur risiko bank dalam pengelolaan pembiayaan/pinjaman yang disalurkan. Rumus NFP/LDR adalah sebagai berikut :

$$
\mathrm{NPF}=\frac{\text { Pembiayaan Bermasalah }}{\text { Total Pembiayaan Yang Disalurkan }} \times 100 \%
$$

$\mathrm{NPL}=\frac{\text { Kredit Bermasalah }}{\text { Total Kredit Yang Disalurkan }} \times 100 \%$

4. Biaya Operasional terhadap Pendapatan Operasional (BOPO)

Rasio BOPO merupakan rasio yang digunakan untuk menilai aspek efisiensi. Aspek ini mengukur bagaimana kemampuan bank dalam pengelolaan dana yang dimiliki dan biayayang harus dikeluarkannya. Rumus BOPO adalah sebagai berikut:

$$
\text { BOPO }=\frac{\text { Biaya Operasional }}{\text { Pendapatan Operasional }} \times 100 \%
$$

5. Return on Assets (ROA)

Rasio ini merupakan rasio yang mengukur kemampuan bank dalam menghasilkan laba dari pengelolaan asset yang dimiliki bank. Rumus ROA adalah sebagai berikut :

$$
\text { ROA }=\frac{\text { Laba Bersih }}{\text { Total Assets }} x \mathbf{1 0 0} \%
$$

Skala pengukuran untuk variabel-variabel dalam penelitian ini menggunakan skala ratio. Skala ratio adalah suatu skala yang merupakan penggabungan dari ketiga sifat skala lainnya. Skala rasio memiliki nilai nol mutlak dan datanya dapat dikalikan atau dibagi.

\section{Metode Analisis data}

1. Analisis deskriptif

Metode analisis deskriptif merupakan metode yang digunakan untuk menganalisis data-data yang tersedia dan diolah sehingga diperoleh gambaran yang jelas mengenai fakta-fakta fenomena yang diteliti.

2. Analisis Uji Beda

Teknik analisis selanjutnya adalah analisis uji beda menggunakan statistic non parametrik. Penggunaan statistic non parametrik digunakan mengingat jumlah sampel dalam penelitian ini relatif kecil. Statistik non parametrik yang digunakan untuk melakukan uji beda adalah wilxocon sign rank test.

\section{PEMBAHASAN}

\section{Analisa Deskriptif}

Sampel bank konvensional dan bank syariah dalam penelitian terdiri dari 3 bank yang cukup besar yaitu Bank Mandiri, Bank BCA dan Bank BNI. Berikut merupakan gambaran umum rata-rata rasio keuangan dari ketiga bank konvensional dan bank syariah tersebut selama periode 2013-2016 yang terdiri dari rasio CAR, LDR, NPL, BOPO dan ROA. 
Tabel 3

Rata-Rata Rasio Keuangan Bank Konvensional

Descriptive Statistics

\begin{tabular}{|l|r|r|r|r|r|r|}
\hline & \multicolumn{1}{|c|}{$\mathrm{N}$} & \multicolumn{1}{c|}{ Minimum } & \multicolumn{1}{c|}{ Maximum } & \multicolumn{2}{|c|}{ Mean } & Std. Deviation \\
\cline { 2 - 8 } & Statistic & \multicolumn{1}{c|}{ Statistic } & \multicolumn{1}{c|}{ Statistic } & Statistic & \multicolumn{1}{c|}{ Std. Error } & \multicolumn{1}{c|}{ Statistic } \\
\hline CAR & 12 & 14.93 & 21.90 & 17.9075 & .67975 & 2.35472 \\
\hline LDR & 12 & 75.40 & 90.40 & 83.3000 & 1.41746 & 4.91022 \\
\hline NPL & 12 & .40 & 3.96 & 1.8675 & .30427 & 1.05402 \\
\hline BOPO & 12 & 60.40 & 80.94 & 67.6250 & 1.85657 & 6.43134 \\
\hline ROA & 12 & 1.95 & 4.00 & 3.3358 & .18011 & .62392 \\
Valid N (listwise) & 12 & & & & & \\
\hline
\end{tabular}

Sumber : Rata-rata CAR, LDR, NPL, BOPO, ROA Bank Konvensional (Mandiri, BCA, BNI) periode 2103-2016

Berdasarkan tabel 3 diatas terlihat bahwa rata-rata CAR bank konvesional selama periode 2013-2016 adalah 17,9075, rata-rata LDR bank konvesional selama periode 2013-2016 adalah 83.3, rata-rata NPL bank konvesional selama periode 2013-2016 adalah 1,8675, rata-rata BOPO bank konvesional selama periode 2013-2016 adalah 67,6250 dan rata-rata ROA bank konvesional selama periode 2013-2016 adalah 3,3358.

Tabel 4

Rata-Rata Rasio Keuangan Bank Syariah

Descriptive Statistics

\begin{tabular}{|l|r|r|r|r|r|r|}
\hline & \multicolumn{1}{|c|}{$\mathrm{N}$} & \multicolumn{1}{c|}{ Minimum } & \multicolumn{1}{c|}{ Maximum } & \multicolumn{2}{|c|}{ Mean } & Std. Deviation \\
\cline { 2 - 7 } & Statistic & \multicolumn{1}{c|}{ Statistic } & \multicolumn{1}{c|}{ Statistic } & \multicolumn{1}{c|}{ Statistic } & \multicolumn{1}{c|}{ Std. Error } & \multicolumn{1}{c|}{ Statistic } \\
\hline CAR & 12 & 12.85 & 36.78 & 20.5450 & 2.43009 & 8.41807 \\
\hline FDR & 12 & 79.19 & 97.86 & 87.9725 & 1.61633 & 5.59912 \\
\hline NPF & 12 & .10 & 6.84 & 2.7275 & .67325 & 2.33220 \\
\hline BOPO & 12 & 84.03 & 100.60 & 90.8367 & 1.30059 & 4.50539 \\
\hline ROA \\
$\begin{array}{l}\text { Valid N } \\
\text { (listwise) }\end{array}$ & 12 & .17 & 1.53 & 1.0158 & .12028 & .41666 \\
\hline
\end{tabular}

Sumber: Rata-rata CAR, LDR, NPL, BOPO, ROA Bank Syariah (Mandiri Syariah, BCA Syariah, BNI Syariah) periode 2103-2016

Berdasarkan tabel 4 diatas terlihat bahwa rata-rata CAR bank syariah selama periode 2013-2016 adalah 20,5450, rata-rata FDR bank syariah selama periode 2013-2016 adalah 87,9725, rata-rata NPF bank syariah selama periode 2013-2016 adalah 2,7275, rata-rata BOPO bank syariah selama periode 2013-2016 adalah 90,8367 dan rata-rata ROA bank syariah selama periode 2013-2016 adalah 1,0158.

\section{Perbandingan Kinerja Keuangan Bank Konvensional dan Bank Syariah}

Setelah mendapat gambaran secara umum kinerja keuangan dengan indikator CAR, FDR, NPF, BOPO dan ROA pada bank konvensional dan bank syariah periode 2013-2016, berikutnya kemudian perbandingan kinerja keuangan bank konvensional dan bank syariah. 
Tabel 5

Perbandingan Kinerja Keuangan Bank Konvensional dan Bank Syariah

\begin{tabular}{|l|r|l|r|}
\hline \multicolumn{2}{|c|}{ Bank Konvensional } & \multicolumn{2}{c|}{ Bank Syariah } \\
\hline \multicolumn{1}{|c|}{ Rasio } & Rata-Rata & Rasio & Rata-Rata \\
\hline CAR & 17.9075 & CAR & 20.5450 \\
\hline LDR & 83.3000 & FDR & 87.9725 \\
\hline NPL & 1.8675 & NPF & 2.7275 \\
\hline BOPO & 67.6250 & BOPO & 90.8367 \\
\hline ROA & 3.3358 & ROA & 1.0158 \\
\hline
\end{tabular}

Dilihat dari tabel 5 terlihat bahwa secara rata-rata CAR bank konvensional lebih kecil di bandingkan dengan CAR bank syariah, dimana rata-rata CAR bank konvensional 17,91 sementara rata-rata CAR bank syariah 20,55. Untuk rasio LDR bahwa secara rata-rata LDR bank konvensional lebih kecil di bandingkan dengan FDR bank syariah, dimana rata-rata LDR bank konvensional 83,30 sementara rata-rata FDR bank syariah 87,97. Untuk Rasio NPL/NPF bahwa secara rata-rata NPL bank konvensional lebih kecil di bandingkan dengan NPF bank syariah, dimana rata-rata NPL bank konvensional 1,87 sementara rata-rata NPF bank syariah 2,73. Untuk BOPO bahwa secara rata-rata BOPO bank konvensional lebih kecil di bandingkan dengan bank syariah, dimana rata-rata BOPO bank konvensional 67,63 sementara rata-rata BOPO bank syariah 90,84. Dan untuk ROA bahwa secara rata-rata ROA bank konvensional lebih besarl di bandingkan dengan bank syariah, dimana rata-rata ROA bank konvensional 3,34 sementara ratarata ROA bank syariah 1,02

\section{Perbedaan Kinerja Keuangan Bank Konvensional dan Bank Syariah}

Setelah melihat gambaran kinerja keuangan bank konvensionaldan bank syariah kemudian membandingkan kedua kinerja tersebut maka selanjutnya akan diuji secara statistik apakah terdapat perbedaan kinerja keuangan bank konvensional dan bank syariah dengan indikator CAR, LDR/FDR, NPL/NPF, BOPO dan ROA. Pengujian secara statustik uji beda menggunakan Wilcoxon signed ranks test. Berikut merupakan hasil uji beda kinerja kuengan bank konvensional dan bank syariah.

\section{Perbedaan CAR Bank Konvensional dan Bank Syariah}

Berdasarkan hasil uji beda antara CAR Bank Konvensional dan Bank Syariah yang terlihat pada tabel 10 , menunjukan nilai sig 0,433 yang berarti lebih besar dari tingkat sig 0,05 sehingga di ambil keputusan Ho diterima Ha ditolak maka dapat disimpulkan bahwa tidak terdapat perbedaan antara CAR Bank Konvensional dan Bank Syariah.

Tabel 6

Hasil Uji Beda CAR Bank Konvensional dan Bank Syariah Test Statistics ${ }^{\mathrm{a}}$

\begin{tabular}{|l|c|}
\hline & CAR KONVENSIONAL - CAR SYARIAH \\
\hline$Z$ & $-.784^{\mathrm{b}}$ \\
Asymp. Sig. (2-tailed) & .433 \\
\hline
\end{tabular}

a. Wilcoxon Signed Ranks Test

b. Based on positive ranks.

c. Based on negative ranks. 


\section{Perbedaan LDR Bank Konvensional dan FDR Bank Syariah}

Berdasarkan hasil uji beda antara LDR Bank Konvensional dan FDR Bank Syariah yang terlihat pada tabel 11, menunjukan nilai sig 0,084 yang berarti lebih besar dari tingkat sig 0,05 sehingga di ambil keputusan Ho diterima Ha ditolak maka dapat disimpulkan bahwa tidak terdapat perbedaan antara LDR Bank Konvensional dan FDR Bank Syariah.

Tabel 7

Hasil Uji Beda LDR Bank Konvensional dan FDR Bank Syariah Test Statistics ${ }^{\text {a }}$

\begin{tabular}{|l|r|}
\hline & LDR - FDR \\
\hline Z & $-1.726^{\mathrm{b}}$ \\
Asymp. Sig. (2-tailed) & .084 \\
\hline
\end{tabular}

a. Wilcoxon Signed Ranks Test

b. Based on positive ranks.

c. Based on negative ranks.

\section{Perbedaan NPL Bank Konvensional dan NPF Bank Syariah}

Berdasarkan hasil uji beda antara NPL Bank Konvensional dan NPF Bank Syariah yang terlihat pada tabel 12 , menunjukan nilai sig 0,657 yang berarti lebih besar dari tingkat sig 0,05 sehingga di ambil keputusan Ho diterima Ha ditolak maka dapat disimpulkan bahwa tidak terdapat perbedaan antara NPL Bank Konvensional dan NPF Bank Syariah.

Tabel 8

Hasil Uji Beda NPL Bank Konvensional dan NPF Bank Syariah

Test Statistics $^{\mathbf{a}}$

\begin{tabular}{|l|r|}
\hline & NPL - NPF \\
\hline Z & $-.445^{\mathrm{b}}$ \\
Asymp. Sig. (2-tailed) & .657 \\
\hline
\end{tabular}

a. Wilcoxon Signed Ranks Test

b. Based on positive ranks.

c. Based on negative ranks.

\section{Perbedaan BOPO Bank Konvensional dan Bank Syariah}

Berdasarkan hasil uji beda antara BOPO Bank Konvensional dan Bank Syariah yang terlihat pada tabel 13, menunjukan nilai sig 0,002 yang berarti lebih kecil dari tingkat sig 0,05 sehingga di ambil keputusan Ho ditolak Ha diterima maka dapat disimpulkan bahwa terdapat perbedaan antara BOPO Bank Konvensional dan Bank Syariah.

Tabel 9

Hasil Uji Beda BOPO Bank Konvensional dan Bank Syariah

Test Statistics ${ }^{\mathrm{a}}$

\begin{tabular}{|l|c|}
\hline & BOPO KONVENSIONAL - BOPO SYARIAH \\
\hline Z & $-3.059^{\mathrm{b}}$ \\
Asymp. Sig. (2-tailed) & .002 \\
\hline
\end{tabular}

a. Wilcoxon Signed Ranks Test

b. Based on positive ranks.

c. Based on negative ranks. 


\section{Perbedaan ROA Bank Konvensional dan Bank Syariah}

Berdasarkan hasil uji beda antara ROA Bank Konvensional dan Bank Syariah yang terlihat pada tabel 14, menunjukan nilai sig 0,002 yang berarti lebih besar dari tingkat sig 0,05 sehingga di ambil keputusan Ho ditolak Ha diterima maka dapat disimpulkan bahwa terdapat perbedaan antara ROA Bank Konvensional dan Bank Syariah.

Tabel 10

Hasil Uji Beda ROA Bank Konvensional dan Bank Syariah Test Statistics ${ }^{\mathbf{a}}$

\begin{tabular}{|l|r|}
\hline & \multicolumn{1}{|c|}{ ROA KONVENSIONAL - ROA SYARIAH } \\
\hline$Z$ & $-3.062^{\mathrm{c}}$ \\
Asymp. Sig. (2-tailed) & .002 \\
\hline
\end{tabular}

a. Wilcoxon Signed Ranks Test

b. Based on positive ranks.

c. Based on negative ranks.

\section{PENUTUP}

\section{Kesimpulan}

Berdasarkan hasil analisa dan pembahasan sebelumnya maka dapat ditarik kesimpulan sebagai jawaban dari perumusan masalah dalam penelitian adalah sebagai berikut:

1. Perbandingan kinerja keuangan dengan indikator CAR, LDR/FDR, NPL/NPF, BOPO dan ROA menunjukan bahwa dengan 5 indikator rasio tersebut bank konvensional dikategorikan sehat untuk semua rasio sementara itu kinerja keuangan bank syariah hanya 4 rasio yang dikategorikan sehat, satu rasio yang dikategorikan cukup sehat yaitu rasio ROA.

2. Perbedaan kinerja keuangan dengan indikator CAR, LDR/FDR, NPL/NPF, BOPO dan ROA menunjukan bahwa hanya rasip BOPO dan ROA yang memiliki perbedaan signifikan tiga rasio lainnya tidak memiliki perbedaan yang signifikan.

3. Dilihat dari penilaian kesehatan bank maka bank konvensional lebih baik dibandingkan bank syariah karena seluruh indikator rasio dikategorikan sehat sementara bank syariah memiliki satu rasio yaitu ROA yang dikategorikan cukup sehat. Kemudian jika dilihat dari perbedaan yang signifikan dari dua rasio yaitu BOPO dan ROA maka nilai rasio BOPO dan ROA bank konvensional lebih baik dibandingkan bank syariah. Maka bisa disimpulkan bahwa kinerja keuangan bank konvensonal lebih baik dibandingkan kinerja keuangan bank syariah.

\section{Saran}

Berdasarkan hasil penelitian maka penulis menyarankan beberapa hal untuk penelitian selanjutnya beberapa hal yaitu :

1. Hasil penelitian menunjukan bahwa ROA antara bank konvensional dan bank syariah berbeda dan ROA bank konvensional lebih baik. Penelitian selanjutnya disarankan untuk meneliti perbandingan faktor-faktor apa saja yang mempengaruhi ROA bank konvensional dan bank syariah. Dengan bisa mengetahui faktor-faktor apa saja yang mempengaruhi ROA diharapkan manajemen baik bank konvensional maupun bank syariah bisa melakukan perbaikan untuk bisa memaksimalkan ROA.

2. Hasil penelitian menunjukan bahwa BOPO antara bank konvensional dan bank syariah berbeda dan BOPO bank konvensional lebih baik. Penelitian selanjutnya disarankan untuk meneliti biaya operasional apa saja pada bank syariah yang membuat BOPObank syariah 
lebih tinggi dibandingkan BOPO bank konvensional, sehingga bank syariah bisa melakukan perbaikan dalam hal efisiensi biaya operasional.

3. Penelitian ini hanya meneliti 3 bank konvensional dan bank syariah maka sebaiknya penelitian selanjutnya menggunakan sampel bank konensional maupun bank syariah yang lebih banyak sehingga lebih mampu memberikan gambaran yang representative terkait kinerjabank konvensional maupun kinerja bank syariah di Indonesia.

\section{DAFTAR PUSTAKA}

Al Arif, M.Nur Rianto. 2015. Pengantar Ekonomi Syariah: Teori dan Praktik. Bandung : CV Pustaka Setia.

Antonio, M.Syafii. 2001. Bank Syariah : Teori dan Praktik. Jakarta: Gema Insani Press.

Iska, Syukri. 2012. Sistem Perbankan Syariah di Indonesia dalam Perspektif Fikih Ekonomi. Yogyakarta: Fajar Media Press.

Putri, Yudiana Febrita, Isti Fadah. 2015. "Analisis Perbandingan Kinerja Keuangan Bank Konvensional dan Bank Syariah" dalam JEAM Vol XIV April (hal 27 - 42). ISSN :1412-5366, e-ISSN :2459-9816.

Purnamasari , Gusti Ayu Yuliani, Dodik Ariyanto. 2016. "Analisis Perbandingan Kinerja Keuangan Bank Konvensional dan Bank Syariah Periode 2010-2014”dalam E-Jurnal Akutansi Universitas Udayana, Vol.15, 1, April (hal 82 -110). ISSN : 2302-8556.

Sabir, Muh M, Muhammad Ali, Abd Hamid Habbe. 2012. "Pengaruh Rasio Kesehatan Bank Terhadap Kinerja Keuangan Bank Umum Syariah dan Bank konvensional di Indonesia" dalam Jurnal Analisis, Juni Vol.1 No.1 (hal 79 - 86).

Setyaningsih, Ari, Setyaningsih Sri Utami. 2013. "Analisa Perbandingan Kinerja Keuangan Perbankan Syariah dengan Perbankan Konvensional" dalam Jurnal Ekonomi dan Kewirausahaan Vol. 13, No. 1, April (hal 100 - 115).

Solikah, Hanina Maya, Ronny Malavia Mardani, Budi Wahono. 2017. "Analisis Perbandingan Kinerja Keuangan Bank Umum Syariah dengan Bank Umum Konvensional di Indonesia" dalam Warta Ekonomi, Vol.07, No.17 Februari (hal 20 -32).

Sovia, Sasa Elida, Muhammad Saifi, Achmad Husaini. 2016. "Analisis Perbandingan Kinerja Keuangan Bank Konvensional dan Bank Syariah Berdasarkan Rasio Keuangan Bank" dalam Jurnal Administrasi Bisnis (JAB), Vol. 37, No.1 Agustus (hal 129 - 136). 